Viktor ZHUKOVSKYY*

\title{
БОЖА ВЕЛИЧ І ПРОВИДІННЯ В БОГОСЛОВ'Ї ІРИНЕЯ ЛІОНСЬКОГО
}

Богословське осмислення природи Божого Буття в апологетичній творчості Іринея Ліонського, відбувається, з одного боку, в гострій полеміці з гностиками, а з іншого, в живому свідченні віри у велич людини, метою життя якої є споглядання і пізнання величі Бога. Богословські тексти Ліонського єпископа багаті на апофатичну термінологію. Бог перевершує всі виміри буття, Він поза і понад усім, що існує. Via negativa Іринея вирізняється радикалізмом у вербальному вираженні абсолютності божественної трансцендентності. На фоні апофатичної категоричності тим яскравішим є контраст, з яким він розглядає зворотній бік божественної схованості. Не виявляючи величі та невимовної слави своєї сутності, Бог робить себе видимим і пізнаваним через посередництво Воплоченого Слова й Божественної Мудрості, які, неначе дві Божі руки, провіденційно турбуються за світ, відкриваючи Бога, який не лише безконечно віддалений, а й безконечно близький людині, яка прагне Його пізнати, комунікує зі світом, просвітлюючи, живлячи і охороняючи його. Динамічно-життєдайна присутність Бога у світовій реальності звершується через енергії Духа, які є дієвим виявом сили Божої та Його щедрості в багатоманітті дарів, якими Він одаровує людину.

Предметом розгляду цієї статті є специфіка апофатичного і катафатичного методів у богословській думці Іринея Ліонського. Особливу увагу звернено на проблему онтологічної відстані між божественним, несотвореним і світовим, сотвореним буттям загалом, та між Богом і людиною зокрема. Мета цього дослідження - представити не лише підхід великого апологета до розуміння безконечної онтологічної дистанції між недосяжною Божого величчю і турботливою присутністю Творця у Його творінні, а й також проаналізувати способи концептуальної інтерпретації всюдисущності трансцендентного Бога в іманентній реальності світу, які пропонує видатний борець з єресями ранньої Церкви.

\footnotetext{
*Viktor Zhukovskyy, PhD, STD - Chair of Theological Department, Ukrainian Catholic University (Lviv); Віктор Жуковський, доктор філософії, доктор богослов'я - завідувач кафедри богослов’я, Український Католицький Університет (Львів)]; e-mail: viktor@ucu.edu.ua.
} 
Структура нашого дослідження має декілька головних елементів. На початку статті буде представлено антиномічну дистанцію між Божою невимовною величчю та Його незбагненним дієвим і життєдайним проявом чоловіколюбності в богослов '̈̈ Іринея. Далі ми розкриємо головні аспекти богопізнання, які Божа воля відкриває для людини у Воплоченому Божому Слові, а також головні концептуальні моделі, якими послуговується Ліонський єпископ, змальовуючи божественну творчу всюдисущність. В цьому контексті розглянемо відому концепцію двох Божих рук, Мудрості і Слова, якими Він, як люблячий Батько, дбайливо піклується світом. Вкінці статті особлива увага буде звернена до Іринеєвого розуміння божественної енергії, як діяльного середника провіденційної, творчої присутність недоступного Бога серед Його творіння.

1. Magnitudinem i philanthropia Бога-Отця. Апофатичний вимір осмислення Божої природи в богословській думці Іринея Ліонського ${ }^{1}$ глибокий та концептуально насичений. Наголошуючи на "іншості" i “"потусторонності” буття Бога щодо світу, Іриней часто виходить із гносеологічних критеріїв, використовуючи "різні атрибути та їхні відповідні іменники і дієслова, щоби виразити верховну Божу трансцендентність щодо людського пізнання"2. Водночас поряд з акцентом на трансцендентному вимірі Божественного Буття він наголошує на протилежному - прямій i реальній можливості богопізнання. Такий патристичний антиномізм яскраво виражений в його богословській думці. Так, наголошуючи на непізнаваності й невизначеності Божої природи, апологет одночасно акцентує на всеохопній і всепронизувальній дії Божої любові.

${ }^{1}$ Іриней Ліонський, найвідоміший християнський апологет II ст., народився у Смирні між 140 i 160 pp. Він залишив Малу Азія і перебрався до Галії, де став єпископом. Найвідоміша його праця - Проти єресей, що складається з п’яти книг, у котрих він гостро критикує гностичні вчення того часу. Детальніше про життя і богословський шлях Іринея див. F.L. Cross, The Early Christian Fathers, London 1960, 109-115. Іриней писав грецькою мовою, але оригінальні тексти збереглися до наших днів лише фрагментарно. На $75 \%$ - Книга I, на 3 \%, 11 \%, 7 \% і 17 \% - відповідно інші чотири книги. Латинський переклад (можливо з III ст.) - це літературний переклад грецького тексту. $€$ також реконструкція оригінального грецького тексту, зроблена у критичному виданні видавцями французького видавництва Sources Chrétiennes. Пор. T.L. Tiessen, Irenaeus on the Salvation of the Unevangelized, London 1993, 8283, п. 2. Детальніше про богослов’я і зокрема про сотеріологію Іринея Ліонського див. Y. de Andia, Homo vivens: Incorruptibilité et divinisation de l'homme selon Irénée de Lyon, Paris 1986; J. Fantino, L'Homme, image de Dieu chez saint Irénée de Lyon, Paris 1986; W.P. Loewe, Irenaeus ' Soteriology: Transposing the Question, в: Religion and Culture: Essays in Honor of Bernard Lonergan, ed. T.P. Fallon - P.B. Riley, Albany 1986, 167-179; idem, Christus victor Revisited: Irenaeus' Soteriology, ATR 67 (1985) 1-15; idem, Myth and Counter-Myth: Irenaeus' Story of Salvation, в: Interpreting Tradition: The Art of Theological Interpretation, ed. J. Kopas, Chicago 1984, 39-54.

2 J. Ochagavia, Visibile Patris Filius: A Study of Irennaeus's Teaching on Revelation and Tradition, OCA 171, Roma 1964, 22. 
“Згідно з Божою величчю (secundum magnitudinem), Бога неможливо пізнати (non est cognoscere), неможливо виміряти (mensurari) Отця. Проте завдяки Його любові (secundum autem dilectionem) це стає можливим. Вона веде нас через Слово до Бога (per Verbum ejus perducit ad Deum). Коли ми Його слухаєм, завжди пізнаємо, що Бог великий і Він Сам влаштував (constituit), вибрав (fecit), прикрасив (adornavit) та утримує все (continet omnia), а у всьому і нас (in omnibus autem et nos), і цей наш світ (mundum)"’3.

Термінологічно-методологічний ключ для розгляду i пояснення божественної трансцендентності для Іринея - “шлях заперечення” (via negativa), в якому через заперечення усіх можливих атрибутів автор показує, ким Бог не є. Т.Л. Тіссен, аналізуючи апофатичний вимір природи Бога в богомисленні єпископа Ліонського ${ }^{4}$, називає низку головних понять, які вказують на те, якою не є Божа природа. Отже, Бог не може бути виміряний (immenserabilis або impossibili mensurari) ${ }^{5}$, Він неосяжний (incapabilis чи $\left.{ }_{\alpha}^{\alpha} \chi \omega ́ \rho \eta \tau \varsigma\right)^{6}$, поза людськими можливостями розуміння (incomprehensibi-

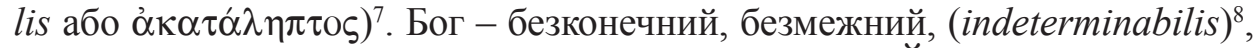

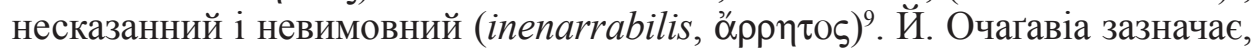
що в богословській думці Іринея Бог - це щось “таємне і таїнственне, що не може бути виявлене"10. Він inexcogitabilis ${ }^{11}$, а також incognoscibilis, тобто Той, хто поза будь-якою концепцією ${ }^{12}$. Бог - загадковий

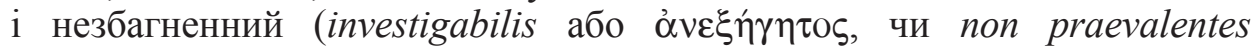

\footnotetext{
${ }^{3}$ Irenaeus, Adversus haereses IV 20, 1, 1-9, ed. A. Rousseau, SCh 100/2, Paris 1965, 624-625: "Igitur secundum magnitudinem non est cognoscere Deum: impossibile est enim mensurari Patrem; secundum autem dilectionem ejus - haec est enim quae nos per Verbum ejus perducit ad Deum obaudientes ei semper discunt quoniam est tantus Deus, et ipse est qui per semetipsum constituit et fecit et adornavit et continet omnia, in omnibus autem et nos et hunc mundum qui est secundum nos. Et nos igitur, cum his quae continentur ab eo, facti sumus". Також див. ibidem IV 20, 1, $\mathrm{SCh} 100 / 2,704$. Іриней часто використовує формулювання Ксенофана, в якому той описує природу Божественного Буття. Згідно 3 характеристикою Ксенофана, Бог “є весь ум, весь дух, вся думка, все почуття, весь розум, весь слух, весь зір, все світло і весь $є$ джерелом будьякого блага" (ibidem II 13, 3). Аналогічні описи можна побачити в Секста Емпірика, Діогена Лаертського, Плінія Старшого, Климента Александрійського, Кирила Єрусалимського й інших філософів і богословів. Детальніше щодо визначень та характеристик Божої природи див. R.M. Grant, Irenaeus of Lyons, London - New York 1997, 44-45.

${ }^{4}$ Пop. Tiessen, Irenaeus on the Salvation of the Unevangelized, c. 82-83.

${ }^{5}$ Пop. Irenaeus, Adversus haereses III 24, 2; IV 19, 2; IV, 20, 1.

${ }^{6}$ Пop. ibidem IV 20, 5.

${ }^{7}$ Пop. ibidem II 18, 2; III 11, 5; IV 20, 5.

${ }^{8}$ Пop. ibidem IV 16, 3; II 25, 4.

${ }^{9}$ Пор. ibidem II 13, 4; IV 20, 5. Також див. Tiessen, Irenaeus on the Salvation of the Unevangelized, c. 82-83.

${ }^{10}$ Ochagavia, Visibile Patris Filius, с. 22, п. 7.

${ }^{11}$ Пop. Irenaeus, Adversus haereses I 14, 1.

${ }^{12}$ Пор. Lampe, c. 134. Irenaeus, Adversus haereses I 15, 5.
} 


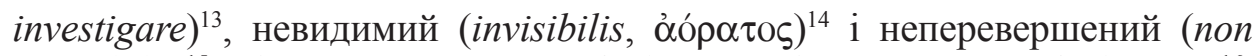

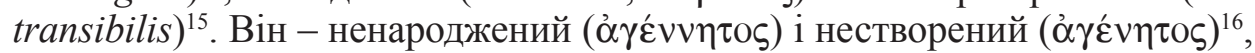
що також перекладають, як ingenitus ${ }^{17}$, infectus ${ }^{18}$, innatus ${ }^{19}$. Бог відділений від сотворених, а отже, від недосконалих сутностей. Таким поняттєвим багатоманіттям насичене апофатичне богослов'я Іринея, в якому він постійно наголошує на тому, що Божа природа поза будь-яким людським вираженням, інтерпретацією, осягненням, розумінням та видінням. Вона перевершує все, що людина знає, бачить чи може уявити. Буттєво Бог перебуває поза і понад всім, що існує.

Такий абсолютний апофатизм, яким, на перший погляд, вирізняється концепція Божественного Буття в богослов’ї Іринея Ліонського, - лише одна сторона його вчення про природу Бога. У полеміці з гностиками він також наполягає й на іншій істині щодо Божого Буття. Бог-Творець у своій любові до людини спілкується з людьми, пронизує своєю присутністю цілий світ, поширюючи свою провіденційну турботу на все розмаїття сотвореної реальності, всі виміри людського життя. Люди покликані бачити Бога ${ }^{20}$, і Бог, входить у сферу людського пізнання, але не відкриває своєї величі (magnitudinem) і невимовної слави (inenarrabilem gloriam) у Його сутності (substantiam/ov่бí $\alpha$ ), яка понад людським осягненням чи оцінюванням ${ }^{21}$. Іриней проводить чітку межу між можливістю богопізнання відповідно до Божої величі й пізнанням Бога у виявах Його любові. Бог об'являє Своє Буття, виявляючи Свою безконечну силу, дієву любов та добру волю щодо людства і світу (philanthropia) 22 . Апологет часто й недвозначно наголошує на неможливості пізнати невидиму і всесильну Божественну сутність, яка являє всемогутню велич та силу Бога у всьому творінні: “Оскільки Його невидима сутність могутня, то подає всім глибоке умове споглядання і сприйняття Його наймогутнішої, чи радше, всемогутньої величі'”23.

${ }^{13}$ Пop. Irenaeus, Adversus haereses IV 20, 5; V 36, 3.

${ }^{14}$ Пop. ibidem II I, 10, 1; III 11, 6; V 16, 2.

${ }^{15}$ Пop. ibidem II $25,4$.

${ }^{16}$ Пор. ibidem I 11, 3. Про різницю між поняттями agennetos i agenetos див. G.L. Prestige, God in Patristic Thought, London 1952, 37-54.

${ }^{17}$ Пop. Irenaeus, Adversus haereses II 34, 2.

${ }^{18}$ Пop. ibidem II 34, 2.

${ }^{19}$ Пop. ibidem IV 38, 1.

${ }^{20}$ Пop. ibidem IV 20, 5; IV 20, 6.

${ }^{21}$ Пop. ibidem IV 20, 1.

${ }^{22}$ Пop. ibidem IV 20, 5.

${ }^{23}$ Ibidem II 6, 1, 4-12, ed. A. Rousseau, SCh 294, Paris 1982, 60-61: “Invisibile enim eiusm cum sit potens, magnam mentis intuitionem et sensibilitatem omnibus praestat potentissimae et omnipotentis eminentiae. Unde etiamsi «nemo cognoscit Patrem, nisi Filius, neque Filium, nisi Pater, et quibus Filius revelaverit», tamen hoc ipsum omnia cognoscunt, quando Ratio mentibus infixus moveat ea et revelet eis quoniam est unus Deus, omnium Dominus". 
Як бачимо, існує певна напруга між трансцендентністю Божого Буття в Його незбагненності та недоступності й пізнанням іманентної “сторони" цього Буття, яке доступне для людського осягнення через динамічний вияв активної Божої любові. Наступне важливе питання, яке постає в нашому аналізі, - це питання онтологічного посередництва між діаметрально протилежними вимірами Божої природи. Іншими словами, що пов'язує трансцендентність та іманентність Бога у світі. Головним посередником ікономічної діяльності Бога, який виявляє свою любов у світі, є Логос-Син ${ }^{24}$.

2. Воля Отця - богопізнання у Слові. Апологет часто і недвозначно твердить про неможливість пізнати невидиму та всесильну Божественну сутність, яка виявляє Божу всемогутню велич і силу у всьому творінні. Для богослов'я Іринея притаманний чіткий антиномізм в осмисленні стосунків між непізнаваним Богом та людиною, яка може в певному сенсі Його пізнати ${ }^{25}$. Можемо знайти подібні протилежні твердження, в яких Іриней розглядає питання можливості також і для ангелів споглядати Бога ${ }^{26}$. Апологет, з одного боку, однозначно підтверджує неможливість пізнати невидиму та всемогутню сутність трансцендентного Верховного Божественного Буття. 3 другого ж боку, Бог стає видимим “за рахунок Його провидіння”, виявляючи велич Його всемогутності й сили у всьому творінні:

"Він [Бог] міг бути для них [ангелів] невидимим відповідно до своєї вищості (esse propter eminentiam), але Він аж ніяк не міг бути незнаним для них завдяки Своєму провидінню (prouidentiam). [...] Оскільки Його невидима сутність могутня (Inuisibile enim eius, cum sit potens), то вона дарує всім глибоке умове споглядання, сприйняття Його всемогутньої і всесильної величі (potentissimae et omnipotentis eminentiae)"27.

Бога можна пізнавати в Його провидінні й діяльній любові через постійну божественну ікономію, що веде людину до Обоження ${ }^{28}$. Головний

${ }^{24}$ Mop. Tiessen, Irenaeus on the Salvation of the Unevangelized, c. 84-86.

${ }^{25}$ Щодо головних аспектів філософської проблеми “примирення” Божественної трансцендентності і вияву Божої доброти відносно світу в богословській думці Іринея також див. R.A. Norris, The Transcendence and freedom of God: Irenaeus, the Greek Tradition and Gnosticism, B: Early Christian Literature and the Classical Intellectual Tradition, ed. W.R. Schoedel - R.L. Wilken, Paris 1979, 87-100; W.R. Schoedel, Enclosing and Enclosed: the Early Christian Doctrine of God, в: Early Christian Literature and the Classical Intellectual Traditionn, c. 75-86.

${ }^{26}$ Пop. Irenaeus, Adversus haereses II.

${ }^{27}$ Ibidem II 6, 1, 4-6. 10-13, SCh 294, 60-61: "Inuisibilis quidem poterat eis esse propter eminentiam, ignotus autem nequaquam propter prouidentiam [...] Inuisibile enim eius, cum sit potens, magnam mentis intuitionem et sensibilitatem omnibus praestat potentissimae et omnipotentis eminentiae".

${ }^{28}$ Іриней одним із перших богословів ранньої Церкви починає розвивати вчення про Обоження (theosis, deificatio), пишучи: “Слово Боже, наш Господь Ісус Христос, який згідно зі 
Посередник (mediator) у боголюдських відносинах - Воплочений Логос, який об'являє Отця сотворінню (Йо. 1,18$)^{29}$. Завдяки цьому об'явленню людині відкривається реальна можливість онтологічно брати участь у життєдавчому світлі Отця, яке веде до божественного життя. Така можливість радикально контрастує з божественною трансцендентністю, яка, недивлячись на потенційну перспективу брати участь у природі Бога, залишається непорушною. Іриней, описуючи зв'язок між трансцендентністю Бога-Отця й іманентністю Воплоченого Божественного Логосу, наголошує на функції онтологічного “мосту” між Богом-Отцем і людиною. Цей "міст”, який поєднує і водночас належить до цих двох діаметрально протилежних буттєвих “берегів”, - Воплочений Логос:

“Коли «Слово стало плоттю» (Йо. 1, 14), то як Слово Боже мало начальство на небесах, так сам Воно мало начальство і на землі; [...] щоб мало начальство і над тим, що під землею, Само ставши «первенцем з мертвих» (Кол. 1, 18). Щоб усі [...] бачили Свого Царя і щоб світло Отця (paterna lux) зійшло на плоть Господа нашого і від Його сяючої плоті перейшло на нас, і так людина оточена світлом Отця одержала нетління (homo deveniat in incorruptelam, circumdatus paterno lumine)"30.

Д.Е. Лане проводить паралель між найвищою і трансцендентною божественною природою, з одного боку, та божественним промислом,

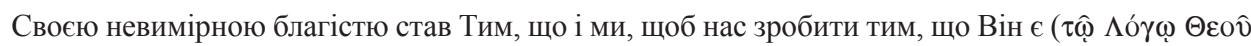

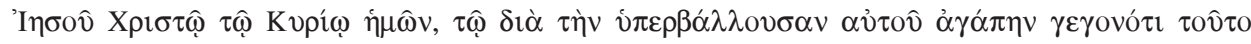

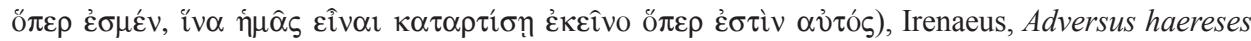
V Praef. 37-40, ed. A. Rousseau, SCh 153, Paris 1969, 15. Іриней говорить про Обоження як участь людини в Божественному Бутті, участь у Божому світлі і його споглядання: “Бо наслідувати Спасителя означає брати участь у спасінні, і наслідувати світло означає приймати світло. А хто у світлі, ті не випромінюють самі світла, але просвічуються та виявляються ним: вони самі нічого не додають йому, але одержують благодіяння, просвітлюються світлом (Sequim enim Salvatorem participare est salutem, et sequi lumen percipere est lumen. Qui enim in lumine sunt non ipsi lumen illuminant, sed illuminantur et illustrantur $a b$ eo, ipsi quidem nihil ei praestant, beneficium autem percipientes illuminantur a lumine)", ibidem IV 14, 1, 10-13, SCh 100/2, 538-539. В іншому місці він пише: “праведні царюватимуть на землі, зростаючи від видіння Господа, і через Нього звикнуть вміщати славу Бога-Отця (Regnabunt justi in terra, crescents ex visione Domini, et per ipsum assuescent capere gloriam Dei Patris)", ibidem V 35, 1, 17-19, SCh 153, 438439. Коментуючи цей текст, В. Лоський (V. Lossky, Vision de Dieu, Neuchatel 1962, 36) пише: “Це напрям думки св. Іринея: обожуюче світло Отця об'являється на землі в переображеному Христі, споглядання Отця, властиве майбутньому віку, може розпочатися вже тут".

${ }^{29}$ Пop. D.E. Lanne, La vision de Dieu dans l'oeuvre de saint Irénée, "Irénikon" 33 (1960) 312-314.

${ }^{30}$ Irenaeus, Adversus haereses IV 20, 2, 42-52, SCh 100/2, 630-631: "Quando Verbum caro factum est: ut, quemadmodum in caelis principatum habuit <quoniam $>$ Verbum Dei, sic et in terra haberet principatum quoniam homo justus, qui peccatum non fecit neque inventus est dolus in ore ejus, principatum autem habeat eorum quae sunt sub terra, ipse primogenitus mortuorum factus; et ut viderent omnia, quemadmodum praediximus, suum Regem; et ut in carnem Domini nostri occurat paterna lux, et a carne ejus rutila veniat in nos, et sic homo deveniat in incorruptelam, circumdatus paterno lumine". Також див. ibidem IV 20, 2, SCh 100/2, 704-705. 
любов’ю, ікономією, діями, світлом, із другого боку. Він порівнює концепцію Іринея 3 подібними підходами до розрізнення між Божественною сутністю й енергією в пізніших богословів ${ }^{31}$. Хоч Іриней ніколи не використовув термін "божественна сутність", проте немає сумніву, що важливим пунктом його вчення про Божу природу було саме "потвердити одночасність некомунікабельності божественної трансцендентності та маніфестації Його любові, через які людина може брати справжню участь у Бозі" ${ }^{32}$.

Згідно $з$ думкою Іринея щодо богопізнання, хоч Бог і відкривається, проте пізнати Його неможливо лише власними силами людини ${ }^{33}$. Бога можна пізнавати лише в тому випадку, якщо Він сам забажає бути пізнаним, і Він стає видимим лише для тих, для кого хоче відкритися, тоді і в той спосіб, яким Він сам воліє ${ }^{34}$. Це - Боже благословення для тих, кому Він бажає відкритись. В іншому місці Ліонський єпископ наголошує, що "неможливо без Бога прийти до пізнання Бога (quoniam impossibile erat sine Deo discere Deum)" "35. Це пізнання - результат доброї волі Бога щодо людства, безперервної божественної ініціативи, “виходу” зі своєї потойбічної реальності в напрямі сотвореного світу і людини.

“Бог від початку сотворив людину вільною, яка має свою владу [...] Богу не властиве насилля, Йому завжди притаманна добра воля. I тому Він всім дає добру пораду"зб.

Для Іринея в пізнанні Бога і полягає справжнє життя людини. Бог хоче, щоб усі його пізнали. Проте люди можуть слідувати Божому керівництву згідно з їхньою власною волею, а не через примус силою з боку Бога ${ }^{37}$.

3. Логос і Софія як дві Божі руки. Центральна концепція, яку пропонує Іриней, щоби вирішити проблему онтологічної “прірви” між божественною трансцендентністю й іманентністю сотвореного світу, - його ідея двох Божих “сил” чи Божих “рук”: Божественного Логосу і Софії, де

\footnotetext{
${ }^{31}$ Пop. Lanne, La vision de Dieu dans l'oeuvre de saint Irénée, c. 319.

${ }^{32}$ Ibidem.

${ }^{33}$ Пop. Irenaeus, Adversus haereses IV 20, 5.

${ }^{34}$ Пop. ibidem IV 20, 5, 108-111, SCh 100/2, 638-639: "Homo etenim a se non videbit Deum; ille autem volens videbitur hominibus, quibus vult et quando vult et quemadmodum vult".

${ }^{35}$ Ibidem IV 5, 1, 16-17, SCh 100/2, 426-427.

${ }^{36}$ Ibidem IV 37, 1, SCh 100/2, 920-921: "Vis enim a Deo non fit, sed bona sententia adest illi semper”. Також див. ibidem IV 14, 2. Про розуміння Об'явлення в святоотцівському богослов' 1 див. М. Rusecki, Objawienie w teologii patrystycznej, VoxP 28 (2008) t. 52, 913-932. Щодо об'явлення в ранній Церкві див. L. de Moor, The Idea of Revelation in the Early Church, "Evangelical Quarterly" 50 (1978) 233.

${ }^{37}$ Пор. Irenaeus, Adversus haereses IV 37, 1. Див. Tiessen, Irenaeus on the Salvation of the Unevangelized, c. 86-93.
} 
Іриней ідентифікує Логос із Сином Божим, а Софію - зі Святим Духом ${ }^{38}$. Відкидаючи претензії гностиків на пізнання недоступної сутності Бога, а також тих, хто знайшов "бога Епікура, який нічого не робить ні для себе, ні для інших, тобто, не здійснює жодного промислу”, Іриней зазначає, що ті, хто пропонують такий образ Бога, не мають правдивого пізнання Його Буття, яке “сходить згори” як божественний промисл у любові та доброті Джерела істини, яку людина пізнає через Боже Слово і Мудрість:

“Тому і світло, що походить від Бога, не світить їм, бо вони принизили і зневажили Бога, дуже низько оцінюючи Його. [...] Він зі своєї любові та невимірної благості (propter dilectionem suam et immensam benignitatem), прийшов задля того, щоб люди пізнали [Його] [...], проте не у величі (secundum magnitudinem) і не в сутності (secundum substanciam), бо ніхто Його не виміряв (mensus) і не охопив (palpauit), але у той спосіб, щоб ми знали, що Він - це Той, хто сотворив і сформував (fecit et plasmauit), вдихнув подих життя (insufflationem uitae insufflauit) і живить нас (nutrit nos) через творіння, все потверджуючи Своїм Словом (Verbo suo) і зв'язуючи Своєю Мудрістю (Sapientia). Він лише Один істинний Бог [...] Вони знайшли бога Епікура, який нічого не робить ні для себе, ні для інших, тобто не здійснює жодного промислу (nullius prouidentiam habentem)"39.

Таким реалістичним усвідомлення того, що безмежно далекий і відсторонений від земних реалій Бог водночас надзвичайно близький, всюдисущий у своєму піклуванні та турботі за світ і людину, наповнені тексти богослова. Іриней постійно бере до уваги біблійну категоричність щодо усвідомлення непрохідного “провалля" між потойбічним Верховним Богом і поцейбічним світом. Проте песимізм радикального трансцендентизму відразу нівелюється оптимізмом другої сторони правди про природу Бога, а саме: реальною можливістю переходу через цю буттєву “прірву" завдяки Божій онтологічній всепронизувальній провіденційній присутності у всіх вимірах іманентного буття, у всьому, що не є Ним самим. Ця динамічна всеохопна Божа проникливість оживляє, охороняє і просвітлює все сотворене:

"Воістину великі небесні скарбниці, Бог невимірний у серці і невмістимий в умі. Він обіймає Своєю рукою землю (immensurabilis est in corde Deus et incomprehensibilis in animo, qui comprehendit terram pugillo). [...] Хто розуміс Його руку (тапит), яка вимірює невимірне (mensurat immensa), яка своєю мірою розкидає міру небес і у своїй долоні утримує землю з безоднями, яка в собі обіймає ширину і глибину, [...] і висоту [...] усього творіння (in se continet latitudinem et longitudinem et profundum

${ }^{38}$ Пор. Irenaeus, Adversus haereses III 24, 2; IV 20, 2; II 30, 9; IV 7, 4; IV 20, 3. Р.М. Грант (Grant, Irenaeus of Lyons, c. 185) зазначає, що ця ідея Іринея розвинулася під впливом Теофіла Антіохійського. Див. Theophilus Antiochenus, Ad Autolycum 1, 7; 2, 18.

${ }^{39}$ Irenaeus, Adversus haereses III 24, 2, ed. A. Rousseau, SCh 211, Paris 1965, 476-479. 
deorsum et altitudinem supernam universae conditionis), яка є видимою, яку можна чути і пізнавати, і яка - невидима? I тому Бог «вище від усякого начала, власти, сили і володарства та всякого імени, яке б воно не було» (Еф. 1, 21), із сотворених і звершених речей (Et propter hoc super omne initium et potestatem et dominationem et omne nomen quod nominatur omnium quae facta sunt et condita sunt, exsistens Deus). Він наповнює небеca, проникає в безодні та присутній у кожному з нас. «Бо Я, - каже, - Бог лише зблизька, [...] а не Бог і здалека? Чи може хтось де-небудь у потайне місце сховатись, де б я його не побачив?» (Срем. 23, 23). Його рука все обіймає (Manus enim ejus apprehendit omnia): вона просвічує (illuminat) небеса і просвічує те, що під небесами, досліджує утроби і серця, наповнює своєю присутністю наші потаємності (absconsis inest et in secretis nostris), явно живить і захороняє нас (in manifesto alit et conservat nos)" ${ }^{\text {"40. }}$.

Очевидно, Іриней у значній мірі вибудовував свою аргументацію в контексті полеміки з гностиками, яким належало вчення про еманації та еони ${ }^{41}$. Саме гностичні еманації, походячи від непізнаваного Верховного Божественного Буття, відіграють роль онтологічного мосту між двома протилежними реальностями: трансцендентною та іманентною ${ }^{42}$. У цьому контексті такі старозавітні метафори, як Божа "рука" чи Божий “палець"43, стають для Іринея термінологічним інструментом для того, щоби змалювати динаміку дієвого божественного входження в сотворений світ. Сам Всевишній Бог задіяний у творчу активність світу. Джерело і каталізатор такого божественного втручання у світ - любов Божа, яка не може себе не виявляти як турботлива і животворяща сила, що надає сенс й уможливлює близьке спілкування Бога зі всім творінням. Тобто для Іринея Бог не відокремлений і нерухомий абсолют, а постійно динамічний та дієво присутній у всьому світі44. Через посередництво

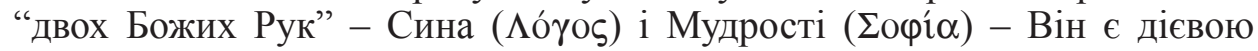
силою в кожному елементі створеної реальності:

“Отже, щодо Божої величі Його пізнати не можна, бо неможливо виміряти Отця, але щодо Його любові, бо вона веде нас через Його Слово до Бога, ми, коли слухаємо Його, завжди пізнаємо, що є такий великий Бог і Він Сам влаштував, вибрав, прикрасив й утримує все, а у всьому і нас, і цей наш світ. [...] Бог не мав ні в чому потреби для сотворення того, що Він призначив для буття у Собі, як нібито Він не мав Своїх рук (manus).

${ }^{40}$ Ibidem IV 19, 2, SCh 100/2, 618-620.

${ }^{41}$ Детальніше про гностичні концепції еманацій й еонів та їх критику Іринеєм див. М.Э. Поснов, Гностичизм II века и победа Христианской Церкви над ним, Брюссель 1991, 666-728.

${ }^{42}$ Пор. J. Lawson, The Biblical Theology of Saint Irenaeus, London 1948, 119-139.

${ }^{43}$ Пор. Вих. 32, 11; Чис. 11, 23; Втор. 5, 15; 6, 21; 7, 8; 9, 26; 26, 8; 34, 12; 1Цар. 18, 46; 2Цар 3, 15; Пс. 44, 3; 71, 18; 77, 15; Ic. 40, 10; 51, 5; 52, 10; 53, 1; Ез. 3, 22; 8, 1; 37, 1.

${ }^{44}$ Пop. Lawson, The Biblical Theology of Saint Irenaeus, c. 135. 
Із ним завжди присутні Слово і Премудрість (Verbum et Sapientia), Син і Дух (Filius et Spiritus), через яких і в яких Він свобідно і зі Своєї доброї волі все сотворив, і до яких Він говорить: «сотворімо людину на наш образ і на нашу подобу» (Бут. 1, 26)"'45.

В. Лоський, коментуючи цей текст, зазначає:

“Ми можемо побачити певне приховане розрізнення, ніби два аспекти в Бозі, - secundum magnitudinem i secundum dilectionem. Можна було би сказати, що Бог, недоступний у Своїй природі, відкриває Себе у Своїй благодаті. [...] У [...] Іринея саме до імені Отця відноситься поняття Божественної природи самої по собі, тоді як поняття Слова він застосовує до об'явлення цієї природи назовні. [...] Син - природній прояв Бога, Він - «видиме Отця», так само, як Отець - «невидиме Сина». [...] Невидимий Бог об'являє Себе, дає Себе бачити у Слові - початку будь-якого об'явлення. [...] Слово і Дух разом та нерозлучно є початком Богоявлення"46.

Отже, через Логос і Софію Бог онтологічно виявляє себе ad extra як живий Бог, постійно динамічний та дієвий Творець, всевідаюча, всепроникна i всепідтримувальна любов. Окрім “Божих рук”, творче Богоявлення звершується також через енергію.

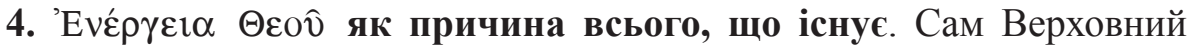
Бог, який понад всіма основами буття, силами, володіннями й іменами, заангажований у всесвітню творчу активність. Як ми бачили у вченні Іринея, джерело походження такої божественної інтервенції в сотворений світ - це любов Бога, яка є самовиявленням божественного життя, його животворящого і найглибшого у своїй близькості зв'язку з кожним елементом Всесвіту. Іриней осмислює Боже єство не як безнадійно віддалене від всього і нерухоме, а як Божественну динаміку спілкування, в якій Бог постійно і дієво уприсутнює себе, активно контактуючи зі світом $^{47}$. Поряд 3 іншими способами ця присутність також здійснюється через божественні енергії. Іриней зазначає, що всіБожі слугиспівпрацюють 3 енергіями Духа: "У Церкві [...] Бог поставив апостолів, пророків, учителів (1Кор. 12, 28) і всі інші (засоби) діяльності Духа (operationem

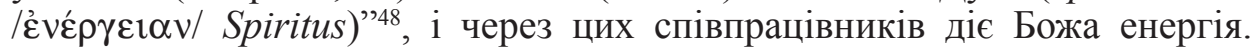
У Фрагментах з втрачених творів Іринея, які до нас дійшли, знаходимо текст, де автор згадує Божу енергію та волю як причину часу, віку, місця

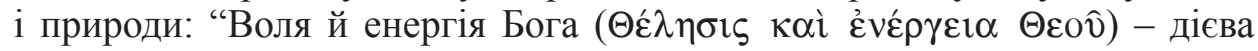

\footnotetext{
${ }^{45}$ Irenaeus, Adversus haereses IV 20, 1, SCh 100/2, 624-627.

${ }^{46}$ Lossky, Vision de Dieu, c. 32.

${ }^{47}$ Пop. Lawson, The Biblical Theology of Saint Irenaeus, c. 135

${ }^{48}$ Irenaeus, Adversus haereses III 24, 1, 22-24, SCh 211, 472-473: "In Ecclesia enim, inquit, posuit Deus apostolos, prophetas, doctores, et uniuersam reliquam operationem (غ̇vé $\rho \gamma \varepsilon \imath \propto \nu)$ Spiritus".
} 
і передбачуюча причина кожного часу і місця, і віку, і кожної природи"49. Незрозумілий, невимовний та недоступний Бог об'являється тим, хто має чисте серце, через Духа, Сина і через Його любов, милосердя й безмежну силу. Силу Божу Іриней описує як світло, яке оживляє тих, хто бере участь у його сяйві і приймає його. Тут в апологета присутній очевидний акцент на синергійній природі богопізнання, яка залежить також від стану глибинного приготування людини. Споглядаючи божественне світло та беручи участь у його сяйві (claritas), людина осягає нетління, яке і є наслідком такого божественного споглядання. Тобто споглядальники Божого світла перебувають у світлі, а відтак у Бозі. Уможливлюючи такий животворний перехід від тління до нетління, відбувається зворотній Божий рух. Бог, залишаючись невидимим і непізнаваним, стає видимим та пізнаваним ${ }^{50}$. У такому розумінні Незрозумілого чи видінні Невидимого божественне сила виявляє Всемогутнього, який “могутній у всіх речах". Неможливо бути осторонь оживляючої присутності цієї всемогутньої сили Бога, Його слави і сяйва:

"Пророки предвіщали, що Бог буде видимий (videbitur Deus) для людей, як і Господь також сказав: «Блаженні чисті серцем, бо вони побачать Бога» (Мат. 5, 8). За величністю (secundum magnitudinem) і дивною славою (inenarrabilem gloriam) «людина не може бачити мене [Бога] i жити» (Вих. 33, 20), бо Отець неосяжний. Але завдяки Його любові і благоволінню до людей (secundum autem dilectionem et humanitatem), а також згідно зі Своєю всемогутністю (omnia possit), Він для тих, хто Його любить, дарує і це, тобто бачити Бога. [...] Людина сама по собі не бачить Бога. Але Він, коли хоче, буває видимим людям, для яких Він хоче бути видимим, коли і як Він хоче. Бо Бог всемогутній (potens est enim in omnibus Deus) [...] Подібно до тих, хто бачить світло, перебуває всередині світла і причащається його сяйву, так i ті, хто бачить Бога, перебуває у Бозі і причащається Його сяйву. Його ж сяйво, животворить їх, тому ті, хто бачить Бога, причасники життя. I тому, Він неосяжний, неохопний і невидимий зробив Себе видимим, охопним й осяжним (incapabilis et incomprehensibilis <et invisibilis > visibilem se et comprehensibilem et capacem hominibus praestat) для віруючих, щоб оживотворити тих, хто приймає і споглядає Його вірою. Бо так, як Його велич недослідима (magnitudo ejus investigabilis), так і невимовною є Його

${ }^{49}$ Idem, Fragmenta deperditorum operum V, ed. W.W. Harvey, B: Sancti Irenaei episcopi Lug-

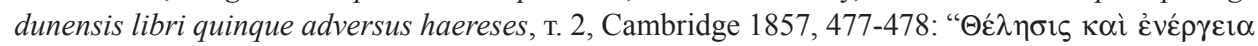

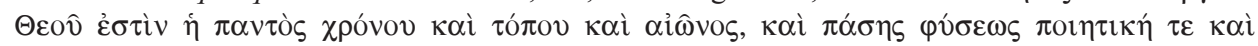

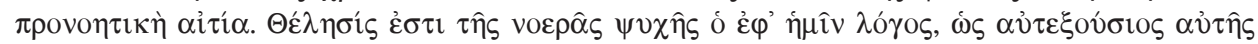

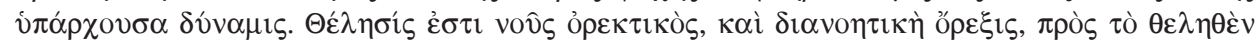

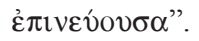

${ }^{50}$ Пop. M.A. Donovan, Alive to the glory of God: key insight in st.Irenaeus, ThS 49 (1988) 288-289. 
доброта (benignitas ejus inenarrabilis), за якою Він буває видимим і дарує життя тим, хто Його бачить. Неможливо жити без життя; а життя походить від спілкування з Богом; спілкування з Богом полягає у спогляданні Бога й насолодженні Його благістю (participatio autem Dei est videre Deum et frui benignitate ejus)" 51 .

В іншому місці четвертої глави Проти єресей Іриней продовжує обговорювати антиномічний підхід в осмисленні природи богопізнання. Він наголошує, що Бога споглядає той, “хто несе Його духа”, чи, іншими словами, “пророчий дух і Його дію, яка простягається на всі види дарів". Іриней тут фактично ототожнює дух із дією, вказуючи на їхній “зовнішній” вимір щодо недоступного та непізнаваного “внутрішнього" виміру природи Бога. Бог-Отець через множинність божественних дій виявляє себе, “виступаючи вперед” і наповнюючи всі матеріальні й духовні творіння. Один і той самий Бог присутній у них активною маніфестацією Себе Самого та через багатоманітні божественні дії дає животворну силу й дари кожному зокрема і всьому в цілості. Величний та невимовний Бог об'являється, відкриваючись духоносцям, у своїх потужних творчих діях, дарах і славі:

“Отже, люди бачитимуть Бога, щоб жити, через видіння, ставши безсмертними і досягаючи навіть до Бога. [...] Бога будуть бачити люди, які носять Його Духа [...] Бо деякі з них бачили пророчий Дух (Spiritum propheticum) і Його дії (operationes), що простягались на всі види дарів (in omnia genera charismatum effusa); [...] інші ж (бачили) славу Отця (glorias paternas), співвідносну з часами і з тими, які бачили і які тоді іiі чули [...] Так відкривався Бог; бо через все це [діï] Бог-Отець об'являється (manifestabatur Deus) [...] Оскільки Бог всього діє у всьому (Sed [quoniam] qui omnia in omnibus operatur [Deus est]), то Він хоч за Своєю природою і величчю невидимий та невимовний (invisibilis et inenarrabilis) для всіх створінь, проте жодним чином не залишається невідомим (incognitus); бо всі творіння через Його Слово пізнають, що є Один Бог-Отець, який все утримує і всьому дає буття (continet omnia et omnibus esse praestat)" ${ }^{52}$.

Логос як Той, “хто поширює благодать Отця”, відкриває Бога в “різноманітних дарах". Іриней постійно притримується антиномічного методу богословлення, коли одночасно говорить про об'явлення і розподіл харизм та "збереження невидимості Отця". Богоявлення в багатоманітності дарів має за мету реалізувати палке бажання людини осягнути повноту свого буття. Людина "завжди повинна володіти чимось, до чого вона може прагнути”. Логос - головний онтологічний посередник, який

\footnotetext{
${ }^{51}$ Irenaeus, Adversus haereses IV 20, 5, SCh 100/2, 636-643.

${ }^{52}$ Ibidem IV 20, 6, SCh 100/2, 642-647.
} 
показує “видимо Бога людям”, а людину представляє Богові. Наголос на антропологічній значимості синергійного підходу - типова патристична характеристика богословської думки Іринея. Саме людина - головна мета богоявлення чи то в Логосі, чи у Софіiі, чи в енергії, силі, сяйві божественного світла та різноманітних дарах. Бо справжня повнота життя людини, яка є славою Божою, залежить від міри боговидіння. А повнота боговидіння i, як наслідок, звершеність життя людини сповнюється завдяки Воплоченню Слова Божого ${ }^{53}$, який відкриває i "розподіляє" славу та благодать Отця, і вводить споглядальника в життєдайний буттєвий і особовий діалог із невидимим Богом.

“Отже, Син Отця від початку сущий з Отцем, від початку відкриває [Його]: Він послідовно в належний час для користі людства, у взаємозв’язку показував людям і пророчі видіння, і різноманітні дари (divisiones charismatum), і Своє служіння, і славу Отця (Patris glorificationem). [...] Слово стало Тим, хто розподіляє Отцівську благодать (dispensator paternae gratiae) для користі людей, заради яких Він зробив такі великі розпорядження, об'являючи людині справжнього Бога, а людину представляючи Богові, водночас зберігаючи невидимість Отця. [...] Показує людям видимо Бога через ці розподіли, щоб чоловік не відпав зовсім від Бога і не перестав існувати. Бо славою Божою є жива людина, а життя людини полягає у видінні Бога (gloria enim Dei vivens homo, vita autem hominis visio Dei). Якщо об'явлення Бога через творіння життєдайне для всіх, хто живе на землі, то тим більше об'явлення Отця через Слово дарує життя тим, хто бачить Бога (per Verbum manifestatio Patris vitam praestat his qui vident Deum)" ${ }^{\prime 54}$.

Божий вияв дієвої любові в Його ікономії дає життя всьому, що існує у світі ${ }^{55}$. Іриней, наголошуючи на неможливості відкритого видіння Божого лиця, одночасно вказує на існуванні певних таїнственних засобів, які відкривають реальну можливість споглядати Божественне Буття.

${ }^{53}$ Пop. Donovan, Alive to the glory of God, c. 290.

${ }^{54}$ Irenaeus, Adversus haereses IV 20, 7, SCh 100/2, 646-649: "Enarrator ergo ab initio Filius Patris, quippe qui ab initio est cum Patre, qui et visiones propheticas et divisiones charismatum et ministeria sua et Patris glorificationem consequenter et composite ostenderit humano generi apto tempore ad utilitatem: ubi est enim consequentia, illic et consonantia, et ubi consonantia, illic et pro tempore, et ubi pro tempore, illic et utilitas. Et propterea Verbum dispensator paternae gratiae factus est ad utilitatem hominum, propter quos fecit tantas dispositiones, hominibus quidem ostendens Deum, Deo autem exhibens hominem; et invisibilitatem quidem Patris custodiens, ne quando homo contemptor fieret Dei et ut semper haberet ad quod proficeret, visibilem autem rursus hominibus per multas dispositiones ostendens Deum, ne in totum deficiens a Deo homo cessaret esse: gloria enim Dei vivens homo, vita autem hominis visio Dei. Si enim quae est per conditionem ostensio Dei vitam praestat omnibus in terra viventibus, multo magis ea quae est per Verbum manifestatio Patris vitam praestat his qui vident Deum".

${ }^{55}$ Пop. Lanne, La vision de Dieu dans l'oeuvre de saint Irénée, c. 317. 
Говорячи про можливість участі людини в божественній тайні, завдяки Божому Слову і Його об'явленням у світі, Іриней згадує пророків, які "відкрито не оглядали самого Божого обличчя, а [вони бачили] веління і таїнства (dispositiones et mysteria), через які людина повинна потім бачити Бога"56.

Підсумовуючи, зазначимо, що богословлення Іринея Ліонського щодо вирішення проблеми онтологічної віддаленості між Божою трансцендентністю та іманентністю наскрізь антиномічне. 3 одного боку, Іриней, як майстер апофатичної богословської термінології, дуже яскраво змальовує незрозумілість, невимовність і неохопність Бога, з другого, апологет, не менш виразно показує, як, той самий, Бог виявляє себе людям, які мають чисте серце і хочуть споглядати і пізнати Його. Вирішення цієї проблеми в богословській думці Ліонського єпископа має дві площини. По-перше, на рівні двох Божих “рук”: Логосу (Син Божий) і Софії (Дух). По-друге, на рівні божественної енергії, сили, сяйва божественного світла і дарів, які животворять тих, хто бере участь у них. Джерело божественного “виходу” ad extra - любов Божа і Його вільне бажання відкрити для людини повноцінну можливість брати участь у Своєму Бутті через Воплочене Слово Боже і в Ньому. Тому важливий акцент, який ставить Іриней у концепції богопізнання, - це Його особова і синергійна природа, яка вимагає глибокої готовності людини прийняти Божу енергію, силу чи світло. У такому пізнанні Непізнаваного, чи спогляданні Невидимого, Боже провидіння виявляє Його і наповнює все творіння своєю життєдайною силою та світлом.

\section{DIVINE GREATNESS AND PROVIDENCE ACCORDING TO THE THEOLOGY OF IRENAEUS OF LYONS}

\section{(Summary)}

The article discusses the problem of the ontological distinction between God's transcendence and immanence in the theological thought of Irenaeus of Lyons, a Church Father of the II-III century. The author presents the main conceptual and terminological apparatus that Irenaeus used in his antinomic approach to the "reconciliation" of apophatic and kataphatic images of God. He analyzes the key characteristics of these two dimensions of the nature of God. Special attention is paid to the analysis of the kataphatic approache in answering the question: how can God, who is completely ontologicaly removed from created reality, be at the same time actively present in the world and filling it. In this context the author analyzes the key notions, which express the "intradivine" remoteness and God's active nearness in relation to created being.

${ }^{56}$ Irenaeus, Adversus haereses IV 20, 10, SCh 100/2, 656-657: "Non igitur manifeste ipsam faciem Dei videbant prophetae, sed dispositiones et mysteria per quae inciperet homo videre Deum". 


\section{BOSKA WIELKOŚĆ I OPATRZNOŚĆ \\ W TEOLOGII IRENEUSZA Z LYONU}

\section{(Streszczenie)}

Artykuł omawia problem ontologicznego rozróżnienia między Boską transcendencją oraz immanencją w myśli teologicznej Ireneusza z Lyonu. Autor przedstawia podstawowy aparat pojęciowy oraz terminologiczny stosowany przez Ireneusza w jego antynomicznym podejściu do „pogodzenia” między apofatycznym i katafatycznym obrazem Boga. Analizuje on właściwości kluczowe tych dwóch wymiarów natury Boga. Szczególna uwaga została poświęcona analizie katafatycznego podejścia do odpowiedzi na pytanie: w jaki sposób Bóg, całkowicie oddalony w aspekcie ontologicznym od rzeczywistości stworzonej, może jednocześnie być aktywnie obecny w świecie i napełniać go? W tym kontekście autor analizuje pojęcia kluczowe, które wyrażaja ,wewnątrzboskie” oddalenie oraz aktywną bliskość Boga w odniesieniu do bytu stworzonego.

Key words: Irenaeus of Lyons, Divine greatness, divine philanthropy, divine hands, Logos, Sophia, divine energy.

Słowa kluczowe: Ireneusz z Lyonu, Boska wielkość, Boska miłość do człowieka, Boskie ręce, Słowo, Mądrość, Boska energia.

Ключові слова: Іриней Ліонський, Божа велич, Божа філантропія, Божі руки, Слово, Мудрість, Божа енергія.

\section{БІБЛІОГРАФІЯ}

\section{Джерела}

Irenaeus, Adversus haereses, ed. A.Rousseau, II, SCh 294, Paris 1982; III, SCh 211, Paris 1974; IV, SCh 100/2, Paris 1965; V, SCh 153, Paris 1969.

IRENAEus, Fragmenta deperditorum operum, ed. W.W. Harvey, в: Sancti Irenaei episcopi Lugdunensis libri quinque adversus haereses, т. 2, Cambridge 1857, 470-511.

\section{Література}

A Patristic Greek Lexicon, ed. G.W.H. Lampe, Oxford 1961.

Andia Y. DE, Homo vivens: Incorruptibilité et divinisation de l'homme selon Irénée de Lyon, Paris 1986.

Cross F.L., The Early Christian Fathers, London 1960.

Donovan M.A., Alive to the glory of God: key insight in st.Irenaeus, ThS 49 (1988) 288-290.

Fantino J., L'Homme, image de Dieu chez saint Irénée de Lyon, Paris 1986.

GRANT R.M., Irenaeus of Lyons, London - New York 1997.

LanNe D.E., La vision de Dieu dans l'oeuvre de saint Irénée, "Irénikon” 33 (1960) 311-320.

Lawson J., The Biblical Theology of Saint Irenaeus, London 1948.

Loewe W.P., Christus victor Revisited: Irenaeus 'Soteriology, ATR 67 (1985) 1-15. 
Loewe W.P., Irenaeus' Soteriology: Transposing the Question, в: Religion and Culture: Essays in Honor of Bernard Lonergan, ed. T.P. Fallon - P.B. Riley, Albany 1986, 167-179.

Loewe W.P., Myth and Counter-Myth: Irenaeus' Story of Salvation, в: Interpreting Tradition: The Art of Theological Interpretation, ed. J. Kopas, Chicago 1984, 39-54.

Lossky V., Vision de Dieu, Neuchatel 1962.

Moor L. De, The Idea of Revelation in the Early Church, "Evangelical Quarterly" 50 (1978) 231-243.

NorRIs R.A., The Transcendence and freedom of God: Irenaeus, the Greek Tradition and Gnosticism, в: Early Christian Literature and the Classical Intellectual Tradition, ed. W.R. Schoedel - R.L. Wilken, Paris 1979, 87-100.

Ochagavia J., Visibile Patris Filius: A Study of Irennaeus's Teaching on Revelation and Tradition, OCA 171, Roma 1964.

Prestige G.L., God in Patristic Thought, London 1952.

Rusecki M., Objawienie w teologii patrystycznej, VoxP 28 (2008) t. 52, 913-932.

Schoedel W.R., Enclosing, not Enclosed: The Early Christian Doctrine of God, B: Early Christian Literature and the Classical Intellectual Traditionn, ed. W.R. Schoedel, R.L. Wilken, Paris 1979, 75-86.

TIESSEN T.L., Irenaeus on the Salvation of the Unevangelized, London 1993.

Поснов М.Э., Гностиичизм ІІ века и победа Христианской Церкви над ним, Брюссель 1991. 